\section{On the rocks down under}

\author{
Michael Audley-Charles
}

Phanerozoic Earth History of

Australia.

Edited by J.J. Veevers.

Clarendon: 1985. Pp.418. £55, \$75.

REGIONAL geology is concerned with how particular areas of the outer part of the Earth have evolved. It attempts to account for all aspects of the rocks that can be mapped at and below the surface. The history of vertical and lateral movements, changes in climate, environments of deposition, rates and modes of erosion have to be interpreted from the great variety of observations, many of which are qualitative or descriptive. Magmatic, metamorphic, sedimentary and deformation processes have to be related in space and time to identifiable regional tectonic events that are often diachronous.

The elephant trap for writers of regional geology is to smother the reader in a snowstorm of detailed descriptions that fail to discriminate between the trivial and the vital. Readers thus afflicted, especially perhaps undergraduates, are led to associate regional geology with tedium. For this book, John Veevers has gathered together a team of writers who cover 575 million years of evolution of a region which represents a fortieth of the Earth's surface and a sixteenth of the continental lithosphere. Australia has no elephants and these authors eschew snow.

The apparent polar wander paths reveal that after some dalliance in the northern tropics during the early Palaeozoic, Australia has stayed in the Southern Hemisphere for most of the Phanerozoic. Records of oceanic palaeomagnetism for the last 160 Myr show how Australia's continental margins have been formed by a "can opener" type of rifting sequence which progressed from the north about 160 Myr anticlockwise around the margins to reach the Coral Sea about $60 \mathrm{Myr}$. These oceanic data do not reveal where or how these events began in what is now central New Guinea about $200 \mathrm{Myr}$. The origin of Australia's northern rifted margin before its late Cenozoic collision is not made explicit.

The evolving sequences of palaeoclimates and palaeoenvironments related to continental drift are dealt with deftly, the authors citing what they judge to be the three or four most sensitive and reliable diagnostic pieces of evidence for each Phanerozoic System of rocks, while a 25-page discussion of Australia's biogeography provides a glimpse of many unsolved problems and some of their seemingly more important implications. For example the tantalizingly uncertain data for Australian angiosperms leave us

successions nor for a biostratigraphical discussion of the faunas and floras; the stratigraphy tends to be underlain by tectonic rather than biostratigraphic concepts. Sedimentological information is used throughout, but much of the text allows the fossils to sleep quietly (unmentioned) in their graves, so much so that some palaeontologists may turn in theirs. Perhaps that highlights the distance between stratigraphy and regional geology - a divorce not to be encouraged.

This book takes a refreshing approach to the synthesis of stratigraphy and tectonics, helped by writing which is concise without being over-condensed. Not only have Veevers and his colleagues produced an attractive and readable account of Australian geology, but more than in any other text I have seen succeed in conveying the excitement of regional geology.

This is not an encyclopaedic account of Australia's Phanerozoic geology. The reader should not expect to turn to the book for detailed description of particular

Michael Audley-Charles is Professor of Geology at University College London.

\section{Chemists' enzymes}

\section{Richard Perham}

Enzyme Chemistry: Impact and Applications.

Edited by Colin J. Suckling.

Chapman \& Hall: 1984. Pp.255.

£17.65, $\$ 36$.

The Chemistry of Enzyme Action.

Edited by M. I. Page.

Elsevier: 1984. Pp.568.

\$66.50, Dfl. 179 .

CHEMISTS have much to learn from, as well as contribute to, the study of enzyme catalysis. Although we no longer stand in awe at the catalytic power of enzymes, it is plain that there are still formidable problems to grapple with before we can claim a satisfactory understanding of their mechanisms. It is equally evident that we have not yet managed to apply all the lessons we have learned to, say, the industrial use of existing enzymes or the design of other catalysts.

Enzyme Chemistry is avowedly a didactic book, which sets out to document some of the past and to illuminate some of the future in the chemical study of enzymes and their products. As Kluger observes in an opening chapter which skilfully reviews the underlying physical organic chemistry of enzymes, if we were given the detailed three-dimensional structure of a protein of undisclosed catalytic specificity, it is unlikely that we could deduce the reaction catalysed. The goal of biomimetic chemistry - the design and construction of molecules that rival enzymes as catalysts is thereby put in perspective. Shinkai concentrates on an encouraging approach to this goal that begins with a thorough study of the chemistry of coenzymes, (01985 Nature Publishing Group whereas Colin Suckling addresses the question of selectivity in chemical and enzyme synthesis. The fastidious selectivity and exquisite stereochemical preferences of enzymes are, of course, now well known but - as Suckling gently reminds us their use has sometimes been treated, a little scornfully, as unacceptable in the perfect total synthesis. He cites some splendid examples of a more robust attitude and of its beneficial effect on biomimetic chemistry.

Industrial chemists have never shunned an enzyme or even whole cells as a means to an end. This theme is taken up by Hesp and Willard in a lively and optimistic discussion of enzyme chemistry and drug design. A rational approach to chemotherapy has seemed just around the corner for almost 50 years, ever since the discovery of the biochemical basis of sulphonamide antibiotics. That prospect still tantalizes but one perceives a quickening of step as the new sophistication of enzyme and protein chemistry and of molecular modelling begins to impinge. Similar optimism is advanced by Cane in a neat chapter on the enzymes responsible for the biosynthesis of natural products. Those chemists who still resist the use of enzymes in total synthesis will be shocked to find his advocacy of the use of recombinant DNA techniques to facilitate a study of the enzymes involved. Bornyl pyrophosphate synthetase, an enzyme of monoterpene biosynthesis, has an estimated turnover number of $10 \mathrm{~mol}$ of substrate per mol of enzyme per hour. Cane flatters this enzyme (he is obviously but justifiably fond of the pathway) by referring to its catalytic power as extremely modest. Given that this may be typical of secondary metabolic enzymes, chemists would be foolish indeed to reject the help that molecular biology can offer them. They might even indulge in the delights of site-directed mutagenesis. 